\title{
Expo Milano 2015: The Institutionalization of Working for Free in Italy ${ }^{1}$
}

\author{
Roberto Ciccarelli
}

\author{
Translated by Roberta Buiani and Enda Brophy
}

\begin{abstract}
This essay reports on the temporary and unpaid forms of labour around which the 2015 World's Fair (Expo 2015) in Milan is organized and upon which it depends. The collective agreement supporting Expo 2015 is especially significant, the paper contends, in that it has been seized upon by the government of Matteo Renzi as a blueprint for the future of labour relations in Italy. Expo 2015 ushers in the institutionalization of unpaid work in the crisis-stricken Italian economy-a transformation approved by the major Italian trade unions that signed off on the collective agreement, but forcefully opposed by social movements who have decried the expansion of unpaid work permitted by the contract.
\end{abstract}

Keywords: Expo 2015, precarious employment, internships, volunteering, free labour

\section{1. "Why the Hell Are You Asking Me to Volunteer?"}

Take 18,500 young people and student volunteers, all working for free, while the judiciary investigates a million dollar bribery scheme, prosecuting and arresting entrepreneurs and corrupt lobbyists. Welcome to the Milan Expo. ${ }^{2}$ Throw in a communications team which routinely turns to the web to ask for "advice" on how to improve the event (one that senior figures in the Italian government maintain will contribute to the country's economic recovery). Add to this the most brilliant and critical activist network in Italy and you'll get a glimpse of what the future has in store for the precariat in this country: unpaid work. These are the elements that, on May 21, 2014, combined to produce what we could rightly call a communicative "epic fail." For the first time since the confederal trade unions and Expo Ltd. signed a collective agreement in July of 2013, Expo 2015 organizers clumsily sought to engage the internet in the discussion of a topic that-like the unspeakable (in Latin, nefas) in Greek tragedy-makes everybody feel uncomfortable and thus usually remains unspoken. ${ }^{3}$

Launched by the event's organizers, the hashtag \#AskExpo was soon flooded by the messages of hundreds of people demanding explanations regarding a collective agreement that, for the first time in the history of Italian labour law, enshrines free work for 90 percent of those involved in the production of what Premier Matteo Renzi sees as a "source of pride" for the country (Expo 2015). Meanwhile, only 835 people among the thousands of interns, apprentices, and limited contract workers will be "hired" for a period of 7 to 12 months. "Why is \#Expo2015-an event that was supposed to create jobs-depending on volunteers?" wrote @TwashWish. "This public event supported by public funds is $90 \%$ dependent on unpaid work. Why are the private companies the ones making money?" asked @ufo_inthesky.

It was impossible not to draw connections between all of this free labour and the arrests of a bid-rigging racket of contractors (the so-called "Cupola degli appalti") carried out on May 8, 2014. Among others, those detained included the General Manager of Expo 2015 Ltd., Angelo Paris, and a number of entrepreneurs and lobbyists recruited from the ranks of the Tan-

\footnotetext{
${ }_{2}^{1}$ An earlier version of this piece was originally published in Alias, May 24, 2014.

2 The Milan Expo is the most recent iteration of a long tradition of "World's Fairs," or public exhibitions held in cities around the world, dating back to the 19th century. Since 1928 the Bureau of International Expositions, headquartered in Paris, France, has taken on the responsibility for co-ordinating the exhibitions.

${ }^{3}$ Translators' note: The labour agreement was signed between Expo and Italy's three major trade unions: the Confederazione Generale del Lavoro (Italian General Confederation of Labour, or CGIL), the Confederazione Italiana Sindacati Lavoratori (Italian Confederation of Workers' Unions, or CISL) and the Unione Italiana del Lavoro (Union of Italian Workers, or UIL).
} 
gentopoli scandal of the early 1990s. "With all the money you've gotten (some of it mysteriously vanished), why the hell are you asking me to volunteer?" tweeted @divexdj.

\section{Anatomy of an Unpaid Workforce}

Following this controversy, Expo 2015 organizers assured the public that the number of interns and volunteers had been reduced to less than 10,000 and that 7,000 of these will be employed for a maximum of 14 days. There was no explanation offered for the diminished numbers-perhaps the organizers feared the unpaid volunteers might not demonstrate the enthusiasm that was originally anticipated. The Expo volunteer program itself includes at least three tracks. A "short-term experience" option is available for those who want to commit five and a half hours a day to the event over a two-week period. "Long-term volunteers" will be able to participate more extensively through civil service projects connected to the event or through projects coordinated by the event's volunteer program, DoteComune Expo, working for five days a week during the six months Expo is staged. A further form of volunteering is referred to as "volunteers for a day", and includes corporate volunteers who will work at Expo for a one-time, five-hour day. Students from Progetto Scuola (The School Project) will act as guides for their peers through the pavilions. Screening of candidates for all of these positions are managed by the Centri di Servizio per il Volontariato (Volunteering Service Centres) which will train the selected volunteers.

The plans laid out by Expo organizers have included the hiring of 640 workers on temporary contracts and 195 interns at a monthly pay of 516 Euro. More than 300 of these shortterm positions have prioritized workers who are either unemployed or receiving social assistance. In all likelihood, at the end of the exhibition, these individuals will return to a state of precarity, hoping for a call to work at a festival or some other event generated by the virtually bottomless reservoir of immaterial labour in the city of Milan.

One of the most disturbing aspects of the working arrangements at Expo is the creation of a two-tier system dividing temporary workers and volunteers: on one side there are the shortterm contractors, the apprentices, and the interns, who will obtain certifications with titles such as "event manager", "big event specialist", or "big event technician and manager". On the other side are the vast majority of volunteers, who work for free and must demonstrate an appreciation of Expo's "values", namely, "feeding the world" and "ensuring quality, healthy, just and sustainable nutrition"-values that are widely shared, to be sure. In short, Expo 2015 demands of its over 10,000 volunteers an (mostly) unpaid commitment in exchange for some visibility and a chance to showcase their talents and broaden their relational networks, all in the hopes of another internship, a short-term contract or perhaps even a job down the road.

\section{The Political Economy of Visibility}

The volunteers, interns, and temporary workers at Expo 2015 share a single destiny: a revolving-door scenario in which they will move between jobs in the formal and informal economy, between unemployment and apprenticeships, between precarious jobs and working for free. With the approval of the confederal trade unions, the Milan Expo has thus become a crucial first step toward the institutionalization of underpaid and free labour in Italy. By relying on a network of volunteering agencies and non-profits, this system puts precarious workers and volunteers in competition and harvests their hopes with the justification that "it's better than nothing." In other words, better to work for free than to be unemployed.

By participating in Expo, by working shifts of six hours a day for six months, these young people will acquire the most coveted commodity in circulation in the era of financialized capitalism: visibility, or, the possibility to show themselves off and prove their existence in this world, hoping that one day this existence will come to have some value in the market. Whether real or only promised, this visibility is most certainly not a commodity: in actual fact,

\footnotetext{
${ }^{4}$ Translators' note: The Tangentopoli scandal, which broke in the 1990s, revealed sweeping corruption across the major Italian political parties of the post-World War II era-the Democristians, the Italian Socialist Party, and the Italian Communist Party-effectively ending their control over Italian politics.
} 
Expo volunteers will receive no money in exchange for their efforts. Technically, theirs is neither a job contract nor can it be considered job training. Volunteers' presence around the pavilions is purely performative. Both Expo organizers and the confederal unions encourage the volunteers' participation as a form of ethical engagement. This engagement, one reads in the agreement endorsed and signed by the unions and Expo Ltd., has to be offered exclusively "with the goal of actively participating, as a gesture of solidarity and pluralism" (Expo 2015 et al. 2013).

"Ethics" here is a key concept in the neoliberal management of labour. The individual is asked to subscribe directly and without mediation to the goals and values imposed from above by the private company or by the state. Participation must be spontaneous, disinterested, and voluntary. That is, the individual has to demonstrate maximum availability and a commitment to the ethics and values of the market, as well as to the principles of the social economy, in this case the "green economy" in particular. The individual's availability must be so broad and indiscriminate as to turn the labour relationship into one of self-exploitation. In other words, the volunteer at Expo is the quintessential 21st century worker. In exchange for zero Euros, she invests what Marx called "absolute surplus labour"-or the excess of work which cannot be measured in terms of wages-in response to the requests of a given firm. Maybe one day she will receive some form of compensation from working precariously for one, two, or three months, for another big event to be programmed in an indeterminate future. It will be up to big investors or the state to organize-whether it is in Milan or in any other city in Italy or in the world-another event that might catalyze sufficient funding to pay today's precarious work force.

\section{New Labouring Subjects}

The great contractual novelty of Expo resides in the fact that the trade unions have fully endorsed an agreement that introduces the notions of "volunteering" or "volunteer" labour. In other words, free labour. Volunteering exists already everywhere in Italy, as in the rest of the world. Its nature is generally religious, political, or civic. The conventions of the big political parties are teeming with young people who lend their free time in exchange for the opportunity to participate in an event. However, Expo is neither a religious event nor the Festa dell'Unita. ${ }^{5}$ Expo is a capitalist enterprise with a long history dating back to the nineteenth century.

The co-opting of volunteers is of course a constant in big, spectacular events: the Olympics and a range of other kinds of cultural events have relied on volunteer labour for many years. This does not take away from the fact that, in the context of Italian law and the recent history of the country's trade unions, what is happening with Expo in Milan is without precedent. In fact, this event has formalized the existence of a double labour market that the trade unions intend to manage along with capital and the state: on one side, there are the precarious worker and the unemployed; on the other side, there are the younger generations, those without "work experience", as well as workers in the informal economy, the chronically unemployed, and those that are "inactive" in that they are no longer even seeking work. These figures merge into a three-fold subject: the worker/precarious/unemployed. In the past, these three conditions constituted three different statuses. Today they coexist in the same individual. This individual can gain regular working experience, as well as engage in precarious work or suffer a period of unemployment, all within a few months. She might even find herself in all three conditions at the same time. In other words, the volunteer at Milan Expo represents the future subject of work living in an immense grey area of informal and precarious labor. This is the condition of what Giorgio Allegri and I have described elsewhere as the Fifth Estate (Allegri and Ciccarelli 2013). ${ }^{6}$

\footnotetext{
${ }^{5}$ Translators' note: The Festa dell'Unità is the traditional yearly celebration of the Italian Communist Party.

6 "The Fifth Estate is an existential condition for millions of workers, whether self-employed, temporary or freelancer workers, skilled or mobile workers, 'precarious' workers or simply working poor. They are knowledge workers, chain workers, communication or health care workers, mini-job workers, or contract workers in the arts and culture sector. The Fifth Estate, however, is also the condition for millions of non-working people in the age of
} 


\section{No Future}

The Italian government's preference has been clear since July of 2013. Former premier Enrico Letta called for an extension of the Expo labour agreement to all employment contracts before he was removed from office by a party conspiracy led by the current premier, Matteo Renzi. This proposed extension only pertained to the portion of the agreement covering free work and the number of apprenticeships to be offered. What has become obvious however is that the creation of new employment in Italy occurs almost exclusively during these "big events" funded by finance capital. These spectacles are marked by ephemeral work arrangements whose duration is only equal to the event itself, a temporary interruption of structural unemployment, or an occasional variation within the recursive regime of precarity. The sole interest of the State, and likewise of capital, is to maintain a constantly flexible employment regime, as well as to regularly modify labour laws in order to keep wages low and deny individuals the fundamental legislative protections they once enjoyed. It's a regime that is demanded obsessively by transnational governance bodies ranging from the International Monetary Fund to the European Central Bank, and national governments dutifully turn it into reality, as the case of Expo 2015 so clearly demonstrates.

\section{Freedom and Slavery}

The final aspect that this Italian story contributes to a broader reflection on labour rights, precariousness, and the fifth estate is the almost compulsory participation on the part of subjects that is demanded by the governance mechanism of free labour. As a result, the emergent sensibility displayed by these subjects is the result of a double movement: a subjection of the individual to the path imposed by the firm (i.e., ongoing education at no cost to the company) and the subjectivation of the individual who freely accepts work without pay for the prospect of an income or a professional position to be secured in an uncertain future. This mixture of freedom and slavery is typical of contemporary neoliberal subjectivity. It is an attitude that characterizes the subject from the earliest days in the education system, and consigns her in adulthood to permanent failure, cultural and political impotence, and apathy in the workplace and society. It is a self-governing mechanism along the lines of what Etienne De la Boètie would call "voluntary servitude". ${ }^{7}$ In neoliberalism voluntary servitude is a model upon which states invest beginning from the subject's earliest years of existence. In turn, the subject is obliged to accept this model as the only way to achieve social inclusion, a goal important enough that she agrees even to pay for the opportunity to work and survive as a member of the working poor.

This phenomenon is not new in Italy or in the United States. It affects the middle class, independent professions, immaterial labourers, and the knowledge economy in particular. There is nonetheless something new in the situation that is unfolding: unlike the years of the economic boom that saw the rise of the middle class, today the substantial resources that are invested by households toward university education and professional training for their children are chronically undermined by unemployment and mass precarity. In the U.S., debt resulting from borrowing from the state and from the banks has generated a market bubble

unemployment in the European Great Recession (2008 onwards); a condition that affects the existence of young people Not in Education, Employment or Training (NEET) as well as that of over-40s. No rights or protection can be thought of for it. Its subjects are stateless people, as they are excluded from social citizenship, and always subjected to the chance of becoming poor. They are the 'outcasts' of traditional labour law in the crucial transition from the Welfare State to the Workfare of neoliberal governance. The subjects of the Fifth 'precarious' Estate are stateless and outcasts in that they often live without class identity and political community. Although they are the natives of the particular country in which they live, today they are as foreign and barbaric as the migrants in our midst in those same countries. Both these natives and the migrants belong to the "community of those without community'. Their citizenship is without a State, because the State does not recognize their citizenship" (Allegri and Ciccarelli 2014)

${ }^{7}$ According to De la Boètie, "voluntary servitude" is the decision of "a vast number of individuals, of towns, cities and nations" to "allow one man to tyrannize them, a man who has no power except the power they themselves give him, who could do them no harm were they not willing to suffer harm, and who could never wrong them were they not more ready to endure it than to stand in his way" (De La Boëtie 1988, 12). 
that is even bigger than the one that was created by subprime mortgages, and there is talk of a default similar to the one that hit the U.S. in 2007. Members of the so-called middle class between 30 and 40 years of age are no longer able to pay their debts due to a drastic redistribution of resources and job insecurity. Yet the only access to employment, and later on, one hopes, to a middle-class existence, remains to pay in order to find a job.

This situation is not very different from the one we are experiencing in Italy, even though the financial dimensions of this rupture are hardly comparable. In Europe the financialization of society is not as advanced as in the United States. However, the institutionalization of free labour by trade unions, businesses, and the state has evolved on both sides of the Atlantic in very similar ways. The subject with no financial resources or support is asked to pay for a graduate degree or certification courses that promise professionalization, and to work for free in the hopes of being able to get an education through precarious and temporary assignments. It is the ultimate demonstration that for at least another generation capital will need not a skilled middle class (if not in miniscule quantities) but rather a vast proletariat to shape into whatever form is required according to the economic conjuncture.

In the midst of the most postmodern economic event that there is, we are witnessing in Italy a return to the conditions of life and work that were typical of early modernity: seasonal labour, day labour, or free labour as a form of survival for subjects bereft of either financial income or social protection. This leap backwards in time could also lead to the discovery of solidarity, to those forms of individual and collective subjectivation that might bring this new kind of proletariat-as David Harvey (2012) calls it in Rebel Cities-to a radical break with exploitation. This would mean, of course, overcoming that mechanism by which the maximum freedom of the subject corresponds to her maximum self-exploitation.

\section{References}

Allegri, Giorgio and Roberto Ciccarelli. 2014. What is the Fifth Estate? Open Democracy. Accessed June 18, 2015. https://www.opendemocracy.net/can-europe-make-it/giuseppe-allegri-robertociccarelli/what-is-fifth-estate.

Allegri, Giorgio and Roberto Ciccarelli. 2013. I/ Quinto Stato: Perché il Lavoro Indipendente è il Nostro Futuro. Milan: Ponte alle Grazie.

De La Boëtie, Etienne. 1988. La Servitude Volontaire, or the Anti-Dictator [Slaves by Choice]. Egham: Runnymede Books.

Expo 2015. 2015. The Premier Renzi Visits the Site of Expo 2015: "Source of Pride for Italy." Accessed April 15, 2015. http://www.expo2015.org/en/the-premier-renzi-visits-the-site-of-expo-2015--source-of-pride-for-italy.

Expo 2015, CGIL Milano, CISL Milano Metropoli, UIL Milano e Lombardia, UIL TUCS Lombardia, FISASCAT Milano Lombardia, CGIL FILCAMS. 2013. Protocollo Sito Espositivo Expo 2015. Accessed June 18, 2015. http://www.provincia.pv.it/attachments/article/1540/Protocollo Apprendistato EXPO 2015.pdf

Harvey, David. 2012. Rebel Cities. London: Verso.

\section{About the Author}

Roberto Ciccarelli

Roberto Ciccarelli is a journalist and philosopher based in Rome, Italy. His blog can be found at furiacervelli.blogspot.it. 